\title{
Melatonin Ameliorates Cardiac Remodelling in Fructose-Induced Metabolic Syndrome Rat Model by Using Genes Encoding Cardiac Potassium Ion Channels
}

Mehmet Akif Ovali ( $\square$ maovali@hotmail.com )

Çanakkale Onsekiz Mart University Faculty of Medicine: Canakkale Onsekiz Mart Universitesi Tip

Fakultesi https://orcid.org/0000-0002-3672-871X

\section{Rahime Ozlem Oztopuz}

Çanakkale Onsekiz Mart University Faculty of Medicine: Canakkale Onsekiz Mart Universitesi Tip

Fakultesi

\section{Selma Arzu Vardar}

Trakya University Faculty of Medicine: Trakya Universitesi Tip Fakultesi

\section{Keywords:}

Posted Date: March 19th, 2021

DOI: https://doi.org/10.21203/rs.3.rs-317015/v1

License: (1) This work is licensed under a Creative Commons Attribution 4.0 International License. Read Full License 


\section{Abstract}

The authors have requested that this preprint be removed from Research Square. 